\title{
Penyuluhan Hukum tentang Pemahaman Siswa SMK terhadap Bullying dalam Perspektif Hukum Pidana dan Perdata di SMK Dr. Indra Adnan Indragiri College Tembilahan
}

\author{
Indra Muchlis Adnan, Muannif Ridwan*, Vivi Arfiani Siregar \\ Universitas Islam Indragiri \\ anifr@ymail.com
}

\begin{abstract}
Abstrak
Fenomena bullying telah menjadi problem universal. Dampak perilaku bullying sering tidak disadari baik oleh korban, pelaku, maupun orang-orang di sekitarnya. Penyebabnya karena bullying bersifat psikis dan emosional, efeknya tidak dapat langsung terlihat, dan prosesnya berlangsung lama dan perlahan. Minimnya pemahaman terhadap konsekuensi hukum, terutama hukum pidana yang akan menjerat menjadi salah satu penyebabnya. Padahal dalam UU Perlindungan Anak sebenarnya juga memiliki aspek perdata, yaitu diberikannya hak kepada anak korban bullying untuk menuntut ganti rugi material/imaterial terhadap pelaku kekerasan. Tim pengabdian kepada masyarakat Fakultas Hukum Universitas Islam Indragiri melakukan penyuluhan hukum kepada siswa SMK yang masuk kategori kalangan remaja, khususnya di SMK Dr. Indra Adnan Indragiri College Tembilahan tentang pemahaman siswa SMK terhadap bullying dalam perspektif hukum pidana. Kegiatan ini bertujuan agar siswa SMK dapat memahami bullying dalam perspektif hukum pidana, serta memahami implikasi hukum pidana dari perilaku bullying, baik dari sisi sebagai korban maupun sebagai pelaku. Metode pelaksanaan kegiatan ini dilakukan dengan beberapa tahapan, dimulai dari tahap persiapan, tahap pelaksanaan, evaluasi kegiatan, hingga pelaporan hasil. Kegiatan pengabdian kepada masyarakat ditujukan kepada para siswa SMK. Kegiatan ini dihadiri 28 siswa SMK. Hasil kegiatan menunjukkan peningkatan pengetahuan dan pemahaman siswa tentang bullying serta dampaknya dalam perspektif hukum pidana. Luaran yang dihasilkan dari kegiatan ini adalah publikasi ilmiah pada jurnal nasional dari semua rangkuman materi yang disampaikan oleh para pemateri sebagai tambahan referensi tentang perilaku bullying dalam perspektif hukum pidana. Hasil kegiatan didokumentasikan dalam bentuk laporan pelaksanaan dan dimuat dalam jurnal ilmiah agar bisa memberikan manfaat seluas-luasnya secara akademis dan tataran praktis.
\end{abstract}

Kata Kunci: siswa, bullying, hukum pidana

\section{Legal Counseling about Vocational School Students 'Understanding of Bullying in Criminal and Civil Law Perspective in Dr. Indra Adnan Indragiri College Tembilahan Vocational High School}

\begin{abstract}
The bullying phenomenon has become an universal problem. The impact of bullying behavior is often not realized by either the victim, the perpetrator or the people around him. The reason is because bullying is psychological and emotional in nature, the effects cannot be seen immediately and the process is long and slow. Their lack of understanding of legal consequences, especially criminal law, which will ensnare them is one of the causes. In fact, the Child Protection Law actually also has a civil aspect, namely that it grants the right to child victims of bullying to demand material / immaterial compensation for perpetrators of violence. The Community Service Team of the Faculty of Law of the Islamic University of Indragiri took the initiative to provide legal counseling to vocational students who are categorized as teenagers, especially at Dr. Indra Adnan Indragiri College Tembilahan Vocational High School about vocational students' understanding of bullying from a criminal law perspective. Based on the aforementioned phenomena, this activity aims to make vocational students understand bullying from a criminal law perspective, as well as understand the implications of criminal law from bullying behavior, both as a victim and as a perpetrator. The method of implementing this activity is carried out in several stages, starting from
\end{abstract}


Vol. 1, No. 3,

November

2020

pp. $167-173$

e-ISSN:

2722-2004

Title

Legal

Counseling

about

Vocational

School

Students

'Understanding

of Bullying in

Criminal and

Civil Law

Perspective in

Dr. Indra

Adnan

Indragiri

College

Tembilahan

Vocational

High School

Author

I. M. Adnan,

M. Ridwan,

V. A. Siregar

the preparation stage, implementation stage, activity evaluation, to reporting the results. The results of the activity showed an increase in students' knowledge about understanding of bullying and the criminal consequences of bullying behavior. The output of this activity is a scientific publication in a national journal of all material summaries submitted by the presenters as an additional reference on bullying behavior in the perspective of criminal law. In addition, the results of activities are documented in the form of an implementation report and published in scientific journals so that they can provide the widest possible benefit academically and practically.

Keywords: students, bullying, criminal law

\section{PENDAHULUAN}

Perilaku bullying sejatinya sudah sangat meluas di dunia pendidikan kita tanpa terlalu kita sadari bentuk dan akibatnya. Bullying merupakan masalah serius yang harus menjadi perhatian bersama. Perilaku ini umumnya terjadi pada anakanak dan remaja dengan kejadian yang bervariasi di beberapa negara. Secara umum, istilah bullying identik dengan tindakan kekerasan terhadap anak yang terjadi di sekolah. Dalam konteks bullying di sekolah, Riausika, Djuwita, dan Soesetio (2005:50), mengemukakan bahwa bullying sebagai perilaku agresif yang dilakukan berulang-ulang oleh seseorang/sekelompok siswa yang memiliki kekuasaan, terhadap siswa/siswi lain yang lebih lemah, dengan tujuan menyakiti orang tersebut.

Penyebab terjadinya tindakan bullying paling tidak ada tiga faktor, seperti disampaikan psikolog Edu Pscyho Research Institute, Yasinta Indrianti (2015:45), ketiga faktor tersebut adalah: a) karakter berkuasa, selalu ingin menjadi yang terkuat dan dipandang hebat, b) keluarga, yaitu pola asuh orang tua yang otoriter atau permisif, c) lingkungan yang menganggap hal tersebut adalah hal yang biasa hingga perilaku bullying tanpa disadari akan membudaya.

Tindakan bullying di Indonesia bisa dicontohkan dalam kasus penindasan, perpeloncoan, pengucilan, dan intimidasi. Fenomena ini menjadi masalah serius bagi masyarakat secara umum, sebab tindakan bullying di era sekarang bisa terjadi di ruang dan waktu kapan pun jika melihat kemajuan teknologi zaman sekarang.

Menurut Pasal 1 angka 16 UU No. 35 tahun 2014 tentang Perubahan Atas UU No. 23 Tahun 2002 tentang Perlindungan Anak, kekerasan adalah setiap perbuatan terhadap Anak yang berakibat timbulnya kesengsaraan atau penderitaan secara fisik, psikis, seksual, dan/atau penelantaran, termasuk ancaman untuk melakukan perbuatan, pemaksaan, atau perampasan kemerdekaan secara melawan hukum. Berdasarkan pendapat di atas dihubungkan dengan pengertian kekerasan dalam UU perlindungan Anak, maka dapat disimpulkan bahwa bullying termasuk dalam bentuk kekerasan terhadap anak.

Mengingat bullying merupakan tindakan kekerasan terhadap anak, maka menurut UU Perlindungan anak, bullying adalah tindak pidana. Namun di sisi lain, UU Perlindungan Anak tersebut juga memiliki aspek perdata, yaitu diberikannya hak kepada anak korban kekerasan (bullying) untuk menuntut ganti rugi material/imaterial terhadap pelaku kekerasan.

Adapun bentuk-bentuk bullying di sekolah menurut Yayasan Sejiwa (2008:2), dapat dikelompokkan dalam tiga kategori, yaitu:

a. Bullying fisik, meliputi tindakan: menampar, menimpuk, menginjak kaki, menjegal, meludahi, memalak, melempar dengan barang, serta menghukum dengan berlari keliling lapangan atau push up. 
b. Bullying verbal, terdeteksi karena tertangkap oleh indra pendengaran, seperti memaki, menghina, menjuluki, meneriaki, mempermalukan di depan umum, menuduh, menyebar gosip dan menyebar fitnah.

c. Bullying mental atau psikologis, merupakan jenis bullying paling berbahaya karena bullying bentuk ini langsung menyerang mental atau psikologis korban, tidak tertangkap mata atau pendengaran, seperti memandang sinis, meneror lewat pesan atau SMS, mempermalukan, dan mencibir.

Pada prinsipnya, seluruh elemen masyarakat baik negara, pemerintah, masyarakat, keluarga, dan orang tua atau wali berkewajiban dan bertanggungjawab memberikan perlindungan dan menjamin terpenuhinya hak asasi anak sesuai dengan tugas dan tanggung jawabnya.

SMK Dr. Indra Adnan Indragiri College Tembilahan merupakan salah satu sekolah swasta yang berada di tengah kota Tembilahan yang memiliki siswa cukup banyak dengan berbagai latar belakang tingkat sosial ekonomi dan etnis. Berdasarkan beberapa penelitian yang menunjukkan adanya hubungan antara variasi etnis dan tingkat sosial ekonomi dengan kejadian bullying, siswa SMK Dr. Indra Adnan Indragiri College Tembilahan sangat berisiko untuk mengalami kejadian bullying. Selain itu, tayangan acara televisi saat ini yang banyak menunjukkan perilaku kekerasan, seperti sinetron remaja, film layar lebar, dan komedi, hal itu juga meningkatkan risiko remaja untuk meniru tindakan kekerasan yang mereka lihat dalam media. Maraknya penggunaan sosial media melalui internet di kalangan remaja juga berpotensi untuk menjadi salah satu media untuk melakukan cyberbullying.

Berdasarkan latar belakang di atas, diperlukan suatu kegiatan penyuluhan untuk menambah wawasan dan meningkatkan kemampuan siswa SMK Dr. Indra Adnan Indragiri College Tembilahan dalam mencegah, menghadapi, dan akibat hukum bullying di lingkungan sekolah. Kegiatan ini sebagai intervensi awal untuk meningkatkan awareness di lingkungan sekolah terhadap isu bullying, mencegah kejadian bullying yang berisiko terjadi di sekolah, sehingga dapat menciptakan suasana pergaulan yang kondusif dan aman untuk proses belajar mengajar pada siswa di SMK Dr. Indra Adnan Indragiri College Tembilahan, mencegah kejadian depresi dan/atau gangguan psikis lainnya pada siswa SMK Dr. Indra Adnan Indragiri College Tembilahan yang dapat diakibatkan oleh bullying di sekolah.

\section{METODE PELAKSANAAN}

Metode pelaksanaan kegiatan ini dilakukan dengan beberapa tahapan, dimulai dari tahap persiapan, tahap pelaksanaan, evaluasi kegiatan, hingga pelaporan hasil. Kegiatan penyuluhan mengenai cara mencegah, menghadapi, dan akibat hukum bullying dalam perspektif hukum pidana dan perdata yang berisiko terjadi di sekolah, dilaksanakan pada 12 November 2020 bertempat di Aula Serbaguna SMK Dr. Indra Adnan Indragiri College Tembilahan yang beralamat di Jalan Trimas, No. 88 Kelurahan Tembilahan Kota, Kecamatan Tembilahan, Kabupaten Indragiri Hilir, Riau. Kegiatan penyuluhan ini dihadiri kurang lebih 28 siswa, dengan harapan tingkat pemahaman siswa terhadap perilaku bullying dalam perspektif hukum pidana dan perdata dapat terealisasikan dengan baik. 


\section{HASIL DAN PEMBAHASAN}

Vol. 1, No. 3,

November

2020

pp. $167-173$

e-ISSN:

2722-2004

Title

Legal

Counseling

about

Vocational

School

Students

'Understanding

of Bullying in

Criminal and

Civil Law

Perspective in

Dr. Indra

Adnan

Indragiri

College

Tembilahan

Vocational

High School

Author

I. M. Adnan,

M. Ridwan,

V. A. Siregar

Kegiatan penyuluhan hukum ini, diikuti para siswa sebagai peserta. Peserta diberikan materi sosialisasi mengenai pencegahan, cara menghadapi, dan akibat hukum bullying dalam perspektif hukum pidana dan perdata, sehingga dapat meminimalisasi perilaku yang mengarah kepada tindak pidana bullying.

Kegiatan pengabdian kepada masyarakat dalam bentuk penyuluhan hukum mengenai pencegahan, cara menghadapi, dan akibat hukum bullying dalam perspektif hukum pidana dan perdata, secara umum berjalan dengan baik dan lancar. Kepala Sekolah beserta seluruh jajarannya ikut membantu dalam mempersiapkan segala kebutuhan kegiatan, mulai dari tempat, personel, hingga mobilisasi siswa untuk ikut serta dalam kegiatan ini. Peserta kegiatan terdiri dari unsur siswa, dan ada juga dari beberapa guru yang hadir. Lokasi kegiatan bertempat di aula serbaguna Sekolah yang sangat kondusif dan nyaman.

Kegiatan penyuluhan ini diawali dengan perkenalan tim pengabdi dengan siswa dan pihak sekolah yang hadir. Pengabdi terlebih dahulu memperkenalkan diri dilanjutkan dengan penyebaran kuesioner pretest tentang pencegahan, cara menghadapi, dan akibat hukum bullying dalam perspektif hukum pidana, guna mengetahui pengetahuan dasar peserta akan hal tersebut. Dalam kesempatan itu, Pengabdi dalam kegiatan Pengabdian Kepada Masyarakat Universitas Islam Indragiri mengucapkan terima kasih atas penerimaan kegiatan ini, dilanjutkan dengan sambutan Kepala Sekolah SMK Dr. Indra Adnan Indragiri College Tembilahan yang menyampaikan apresiasi dan dukungannya terhadap berlangsungnya kegiatan penyuluhan ini di sekolahnya sekaligus membuka kegiatan tersebut. Setelah itu, kegiatan dilanjutkan dengan pemaparan materi oleh pengabdi sebagai narasumber.

Selama kegiatan berlangsung, tampak peserta sangat antusias mendengarkan paparan materi penyuluhan. Pemaparan materi berlangsung selama kurang lebih 4 (empat) jam dan dilanjutkan dengan sesi tanya jawab di akhir paparan serta pembagian doorprize bagi peserta dengan pertanyaan dan jawaban terbaik. Antusias peserta dalam kegiatan ini terlihat dari pertanyaan-pertanyaan yang muncul untuk kemudian disampaikan jawabannya oleh para pemateri.

Di penghujung kegiatan penyuluhan ini, pengabdi kembali menyebarkan kuesioner post-test untuk mengetahui sejauh mana tingkat pemahaman dan pertambahan pengetahuan siswa akan bullying dalam perspektif hukum pidana dan pencegahannya serta cara menghadapinya. Sebagai wujud apresiasi dari pengabdi, dilakukan penyerahan sertifikat bagi peserta dilanjutkan sesi foto bersama antara pengabdi, siswa, dan jajaran sekolah. Pelaksanaan penyuluhan dapat dilihat dalam pada gambar 2 .

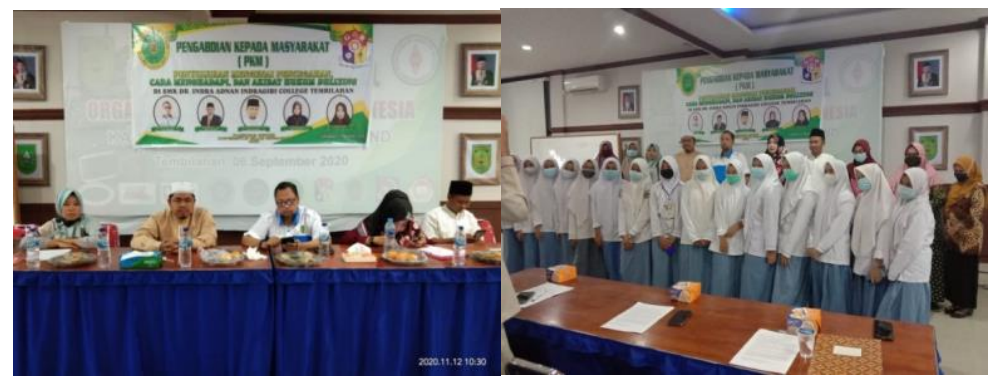

Sumber: Dokumentasi pribadi (2020)

Gambar 2. Pelaksanaan penyuluhan tentang pencegahan, cara menghadapi, dan akibat hukum bullying dalam perspektif hukum pidana dan perdata 
KANGMAS: Karya Ilmiah Pengabdian Masyarakat, 1 (3), November 2020 - 171 http://journal.neolectura.com/index.php/Kangmas

Dari hasil penyuluhan, siswa dapat mengerti dan memahami tentang pencegahan, cara menghadapi, dan akibat hukum bullying, baik itu dilihat dari perspektif hukum pidana dan perdata. Antusiasme siswa juga terlihat dari pertanyaan-pertanyaan yang muncul dalam sesi tanya jawab, antara lain:

1. Terkait kasus tentang bullying, seberapa parah kasus bullying yang terjadi di Indonesia?

2. Bagaimana cara membedakan apakah tindakan itu mengandung unsur bullying atau tidak? Mohon sertakan contohnya!

3. Jika terjadi bullying pada seorang teman, apa saja tindakan yang harus kita lakukan?

Guna mengetahui tingkat keberhasilan kegiatan penyuluhan ini, para siswa peserta penyuluhan diberikan kuesioner. Pemberian kuesioner diberikan dalam dua tahap. Tahap pertama diberikan sebelum mereka mendapatkan materi tentang bullying (pretest). Tahap kedua diberikan setelah mereka mendengarkan pemaparan dari para pemateri tentang bullying (post-test).

Pada tahap pretest ini, setelah pengabdi menyebarkan kuesioner dan mengolah data jawaban dari siswa peserta penyuluhan, maka diperoleh hasil sebagaimana terlihat dalam Gambar 3 berikut ini.

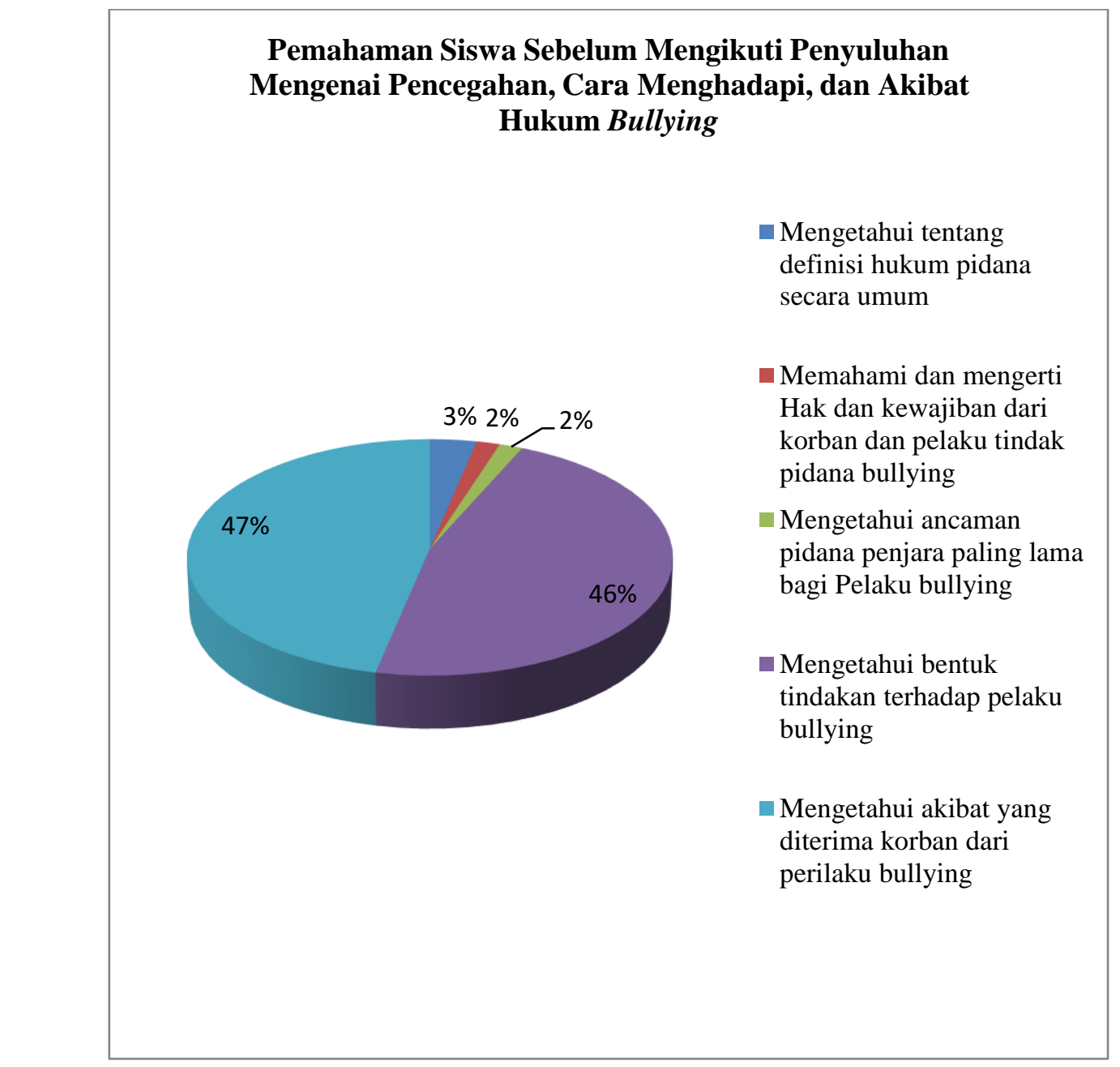

Sumber: Hasil Pelaksanaan PKM (2020)

Gambar 3. Hasil Kuesioner Pretest 
Vol. 1, No. 3,

November

2020

pp. 167-173

e-ISSN:

2722-2004

Title

Legal

Counseling

about

Vocational

School

Students

'Understanding

of Bullying in

Criminal and

Civil Law

Perspective in

Dr. Indra

Adnan

Indragiri

College

Tembilahan

Vocational

High School

Author

I. M. Adnan,

M. Ridwan,

V. A. Siregar

Keterangan Gambar 3:

1. Sebanyak 3\% siswa yang hadir di kegiatan penyuluhan mengetahui tentang definisi hukum pidana secara umum.

2. Sebanyak $2 \%$ memahami dan mengerti hak dan kewajiban dari korban dan pelaku tindak pidana bullying.

3. Sebanyak $2 \%$ dari siswa yang hadir menjawab pertanyaan tentang apakah mengetahui ancaman pidana penjara paling lama bagi Pelaku bullying.

4. Sementara untuk pertanyaan tentang mengetahui tentang bentuk tindakan terhadap pelaku bullying menjawab $46 \%$.

5. Sebanyak $47 \%$ siswa menjawab mengetahui akibat yang diterima korban dari perilaku bullying.

Pada tahap post-test ini, setelah pengabdi menyebarkan kuesioner dan mengolah data jawaban dari siswa peserta penyuluhan, maka diperoleh hasil sebagaimana terlihat dalam Gambar 4.

\section{Pemahaman Siswa Setelah Mengikuti Penyuluhan Mengenai Pencegahan, Cara Menghadapi, dan Akibat Hukum Bullying}
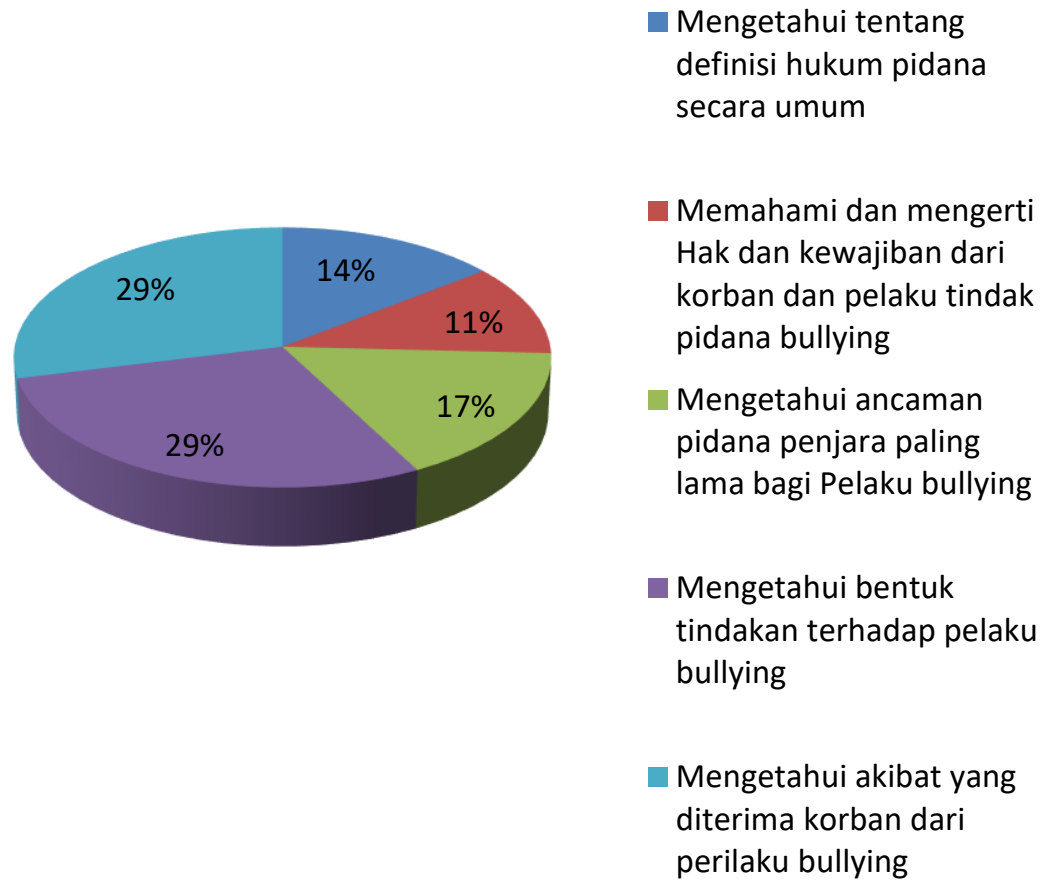

Memahami dan mengerti Hak dan kewajiban dari korban dan pelaku tindak pidana bullying

Mengetahui ancaman pidana penjara paling lama bagi Pelaku bullying

Mengetahui bentuk tindakan terhadap pelaku bullying

Mengetahui akibat yang diterima korban dari perilaku bullying

Sumber: Hasil Pelaksanaan PKM (2020)

Gambar 4. Hasil Kuesioner Post-Test

Keterangan Gambar 4:

1. Sebanyak $14 \%$ siswa yang hadir di kegiatan penyuluhan mengetahui tentang definisi hukum pidana secara umum.

2. Sebanyak $11 \%$ memahami dan mengerti Hak dan kewajiban dari korban dan pelaku tindak pidana bullying.

3. Sebanyak $17 \%$ dari siswa yang hadir menjawab pertanyaan tentang apakah mengetahui ancaman pidana penjara paling lama bagi Pelaku bullying. 
4. Sementara untuk pertanyaan tentang mengetahui tentang bentuk tindakan terhadap pelaku bullying menjawab $46 \%$.

5. Sebanyak $47 \%$ siswa menjawab mengetahui akibat yang diterima korban dari perilaku bullying.

Jika dilihat dari Gambar 4 di atas, dapat ditarik simpulan akhir bahwa hasil peningkatan pengetahuan para siswa peserta penyuluhan tentang pencegahan, cara menghadapi dan akibat hukum bullying dilihat dalam perspektif hukum pidana dan perdata adalah cukup signifikan.

\section{SIMPULAN}

Berdasarkan uraian di atas, dapat disimpulkan bahwa kegiatan pengabdian kepada masyarakat tentang pencegahan, cara menghadapi, dan akibat hukum bullying dilihat dalam perspektif hukum pidana dan Islam di SMK Dr. Indra Adnan Indragiri College Tembilahan telah terlaksana dengan baik dan lancar. Kegiatan pengabdian kepada masyarakat disambut respons positif dari peserta dilihat dari pertanyaan-pertanyaan yang muncul dalam kegiatan penyuluhan tersebut guna menjawab rasa keingintahuan mereka. Demikian juga adanya peningkatan pengetahuan dan pemahaman siswa peserta penyuluhan tentang bullying dalam perspektif hukum pidana. Kegiatan pengabdian kepada masyarakat seperti penyuluhan hukum ini hendaknya dilakukan secara berkesinambungan baik di lokasi yang sama ataupun di lokasi yang berbeda dengan menyasar kepada siswa-siswa lain yang belum sepenuhnya paham akan akibat hukum dari bullying dalam perspektif hukum pidana dan Islam.

\section{DAFTAR PUSTAKA}

Benedikta. (2015). Faktor Penyebab Bully dalam Stelios N Georgiou, "Bullying and Victimization in Cyprus: The Role of Social Pedagogy," International Journal of Pedagogy, Vol. 4, No.1. 45.

Kitab Undang-Undang Hukum Perdata.

Kitab Undang-Undang Hukum Pidana.

Riauskina, Djuwita, \& Soesetio. (2005). Gencet-Gencetan di Mata Siswa/Siswi Kelas 1 SMA: Naskah Kognitif tentang Arti Skenario, dan Dampak "GencetGencetan". Jurnal Psikologi Sosial Vol. 12, No. 01.

Undang-Undang Nomor 23 Tahun 2002 tentang Perlindungan Anak sebagaimana telah diubah oleh Undang-Undang Nomor 35 tahun 2014 tentang Perubahan Atas Undang-Undang Nomor 23 Tahun 2002 tentang Perlindungan Anak.

Yayasan Semai Jiwa Amini (SEJIWA). (2008). Bullying: Mengatasi Kekerasan di Sekolah dan Lingkungan Sekitar Anak. Jakarta: Grasindo. 